\title{
CAPTIVE COAL AND EXEMPTIONS FROM PRICE REGULATION: BITUMINOUS COAL ACT OF 1937
}

Secrion 4-II-(1) of the Bituminous Coal Act of $1937^{1}$ exempts from Code regulation all "coal consumed by the producer or . . . transported by the producer to himself for consumption by him." Designed to exclude from the minimum price provisions of the Act coal extracted from so-called "captive" mines, this section appears destined to be the first, and perhaps an ever-widening, loophole in the legislation regulating the coal industry. The ambiguous terms of the provision have left its scope undetermined. $\Lambda$ current problem for judicial determination, therefore, is the classification of the various "captive" arrangements as exempt or non-exempt within its purview.

In the trade use of the term, "captive" coal is all coal other than that produced for sale in the open market; a "captive" producer is generally regarded as a consumer owning or controlling a coal mine, and consuming its output. ${ }^{2}$ Prior to federal regulation of the coal industry, numerous consumers seeking to obtain regular, low-cost supplies of coal of uniform quality became "captive" producers. ${ }^{3}$ The immediate decision of a coal consumer

1. 50 Stat. 72 (1937), 15 U. S. C. $\$ 828-851$ (Supp. 1939); extended to April 26, 1943, Pub. L. No. 34, 77th Cong., 1st Sess. (Apr. 11, 1941). (Further citations to the Act will refer to the section number only.) Cf. SEn. Rep. No. 169, 77th Cong., 1st Sess. (1941) 3: Acceptance of the bill as it passed the House "is not intended either expressly or by implication, as ratification or approval in any respect of the interpretation of the Act by the Fourth Circuit Court of Appeals or the Supreme Court of the United States in the case [Powell v. Gray, note 22 infra] in question."

2. See Appalachian Coals, Inc. v. United States, 288 U. S. 344, 357, 11. 1 (1933); Miller, The Pricing of Bitnminous Coal: Some International Comparisons in Fuevuren \& Mason, Public PouICY (1940) 145; Hearings Before a Subcommittec of the Committec on Interstate Commerce on S. 1417, 74th Cong., 1st Sess. (1935) 53, 84 (cited hereafter as Hearings). This definition is narrower than the following adopted by the Coal Division: "mines in which the tonnage reported as 'controlled' sales and 'exempt' coal constituted $40 \%$ or more of the total output have been classified as 'captive' . . . for purposes of statistical analysis only . . . not as an interpretation of Section 4, Part II (1)." REvised Detall of Producing, Administrative, and Selling Costs for tue Chlendonk YEAR 1940, Economics Branch, Bituminous Coal Division, No. 147850, June 25, August 19, August 26, 1941. (The analysis covers all United States production but that in Colorado, New Mexico, Wyoming, Utah, Montana, and Washington). The Coal Conservation Act of 1935, held unconstitutional in Carter v. Carter Coal Co., 298 U. S. 238 (1936), although making no captive exemption, defined captive coal to include "all coal produced at a mine for consumption by the producer, or by a subsidiary or affiliate thereof . . ." See $\$ 19,49$ Star. 991, 1008 (1935). The 1935 Act, however, contained labor provisions as well as machinery for establishing minimum prices.

3. "There is a growing tendency for the users of coal to make sure their own supplies. It is apparent all along the line from steel-mills to mail-order houses. It might eventuate afterwhile in a complete dismemberment of the industry, and its apportionment in bits large and small to the industries which it furnishes with power." Hamiloon \& Wright, The Case of Bituminous Conz (1926) 193. 
to buy, lease, or otherwise "capture" a source of coal for his own needs necessarily involved a comparison of market prices and the cost at which captive facilities were available to him. Uncertainties such as the future course of market prices, the threats of unionism, the danger of shortages, and other anticipations as to the development of the coal market directly influenced the consumer's decision to undertake captive operations." Such operations were more or less expensive than a policy of coal purchases, depending on the relationship between the costs of captive coal and prices in the market. The existence of large, untouched coal fields, and of many mines with capacity to produce more than their current output, enabled consumers to resort to captive sources and thus acted as a definite inhilition on price rises in the market. ${ }^{0}$ The history of the industry reveals that captive facilities were acquired and utilized principally during boom periods, the proportion of captive production decreasing during depressions, when many captive producers shut up their own mines, and bought on the open market more cheaply than they could produce. ${ }^{7}$

As a practical matter, the legal relationship of the captive mine to the consumer assumed varied forms. Control of production facilities was often obtained, for example, by the purchase or lease of coal lands or by the acquisition of a security interest in an existing mining enterprise. Mining operations were conducted through a variety of legal instrumentalities including contracts of employment, forms of agency, and independent contractor relations. Most frequent, however, was the use of subsidiary or affiliate corporations, both to control facilities and to maintain operations.

4. Thus, it has been pointed out, the inability to obtain adequate supplies of ras: materials at reasonable prices which is consequent upon "boom" conditions stimulates the consumer to expansion, along lines of supplying his own needs. See Ronmson, TuE Structure of Competitive Industry (1932) 129.

5. Unused resources and new coal fields, machine-mining and the multi-shift day are the basic factors in creating the "menace of potential coal." See H.smitio: \&

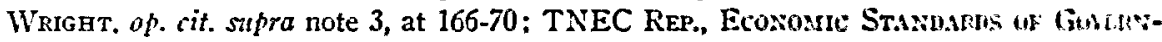
Nient Price Control, Monograph 32 (1941) Pt. III, pp. 23S, 265.

6. "The problem of protecting the consumer against unreasonable advance in prices is simplified in coal mining by the presence of competitive sources uf energy . . . and by the alternative offered to the larger consumers of opening mines for their uwn use. Industrial consumers already supply a fourth of their own requirements frum mines which they control." Excerpt from a Report by the National Resources Committee, Hearings on S. 1417, 74th Cong., 1st Sess. (1935) 386. Hence, while captive coal dues not enter the open market, it competes with all other coal as a potential method of supplying the consumer's needs, to wit: "backward vertical integration." See Evcris:s:, Tne Eco:0:1ICS OF CORPORATE ENTERPRISE (1940) 307.

7. See TNEC Rep., supra note 5, at 242-54, 265; Parker, The Co.al I:nnesnus (1940) 28,38 . In some cases, however, captive oneration has theen characterized by intermittent "dumping." Staebler, The Codl Act-A Case Study in Plazinizit (1940) 7 . 
Under the present Coal Act, "producer" is defined to include all persons and firms "engaged in the business of mining coal." 8 The mininum price provisions and the marketing rules and regulations established under the Code are made inapplicable to transactions involving coal consumed by the producer.9 The total "price" paid by the exempt captive producer for his coal supply is therefore the sum of the costs of producing and transporting it. In escaping the minimum price provisions of the Act he is relieved of meeting a price level which depends on many elements other than cost, and specifically must allow for "taxes, insurance, . . . royalties, depreciation, . . . coal operators' association dues, district board assessments for Boarcl operating expenses only levied under the Code, and reasonable costs of selling and the costs of administration." 10 If, however, exemption is denied, the consumer must pay his supplier the minimum prices set under the Act. ${ }^{11}$ While this payment may be no more than a bookkeeping entry if the supplier is a subsidiary or a branch of the consumer's business, the decision not to allow exemption has other more serious consequences. The supplier must pay substantial dues and assessments under the Code, ${ }^{12}$ submit cost data

8. $\$ 17(c)$. The denotation of the word "producer" in the Act has not yet been given a precise meaning for the purposes of the particular statute. Cf. Foss-Hughes Co. v. Lederer, 287 Fed. 150 (E. D. Pa. 1919); see Oliver Iron Mining Co. v. Lord, 262 U. S. 172,180 (1923).

9. By $\S 3$ (b) producers have the choice of accepting membership in the Coal Code, and abiding by the regulations thereof, or paying the $191 / 2 \%$ tax upon the sale or other disposal of coal "which would be subject to the application of the conditions and provisions of the code . . ." Since producer-consumed coal transactions are not subject to Code regulation, the $19 \% \frac{1}{2} \%$ tax is inapplicable, but apparently the 1 cent per ton tax on the sale or other disposal, "the term 'disposal" including "consumption or tsse . . . by a producer," under $\$ 3(\mathrm{a})$, remains applicable. Cf. Sunshine Antluracite Coal Co. v. Adkins, 310 U. S. 381,392 (1940).

10. \&4-II-(a). Selling costs for coal sold in the open market in districts 1 to $\mathbf{1 5}$ ranged in 1940 from 5.74 cents per ton in district 2 to 29.6 cents per ton in district 14, with an average selling cost per ton for districts 1 to 15 of 11.35 cents. District board assessments under $\$ 4-\mathrm{I}$-(b) in districts 1 to 15 for the last five months of 1940 amounted to $\$ 831,201$. During that time, production for these districts was roughly 175 million tons. Statistics computed from totals in Revised Detail of Producing, Administrative, and Selling Costs for the Calendar Year 1940, op. cit. supra note 2. Sec 'TNEC REP., supra note 5, at 266-67. In financial reports to stockholders, two private companies reported total Code taxes and assessments of "approximately $\$ 200,000$," on a tonnage estimated at 2,500,000 (Annual Report, 1940, Island Creek Coal Co., 8) and $\$ 66,000$, on an estimated 750,000 tons produced. (Annual Report, 1940, Pond Creek Pocahontas Co., 5). Thus it was testified in the Hearings Before The Commiltec On Ways and Means on H. J. Res. 101, 77th Cong., 1st Sess. (1941) 6, "The industry has many millions of dollars invested in this Act. It has paid more than $\$ 15,000,000$ in taxes levied by the Act to defray administrative expenses. In addition it has paid assessments to its district boards and has incurred the expenses of hearings, lawyers' fees and so forth." (Harold L. Ickes).

11. See $\$ \S 3(b), 5(b)(4)$.

12. \$4-I-(b); see note 10 supra; cf. McLean Coal Co. v. Pittsburgh Terminal Corp., 328 Pa. 250, 195 Atl. 4 (1937). 
and frequent reports of operations, and run the risk of lengthy and expensive examination and cross-examination on issues relevant to the administrative process of setting minimum and now maximum prices. ${ }^{13}$ Where the captive arrangement involves a parent-consumer and a subsidiary-supplier, receipt of minimum price payments will probably render the subsidiary liable for income taxes; in addition, income taxes on $15 \%$ of any dividends paid by the subsidiary pursuant to its increased income will be assessed against the parent. ${ }^{14}$ This state of facts has created pressure in two directions: first, captive producers already having control of mines have pressed insistently for a liberal exemption-granting policy $\mathbf{:}^{\mathbf{1 5}}$ secondly, large consumers desirous of obtaining the benefits of the exemption provision without the financial responsibility of actually purchasing and operating a mine, have sought captive arrangements with independent mine operators. Moreover, captive arrangements may have definite advantages for the formerly independent operator as well as for the consumer. Where, for example, he hecomes an agent-operator receiving payment on a tonnage basis, the lowered rate of profit per ton is compensated for by a higher volume and more stable rate of production, ${ }^{16}$ and, consequently, higher ultimate profits measured with reference to capital. ${ }^{17}$

If the multitude of legal arrangements available to the prospective captive producer were held exempt under the Coal Act, a serious interference with its administration would result from increases in dues and assessments for the operators who remain non-captive, and the disappearance of accurate marketing cost data, the elements of which will be non-existent or merged in the direct marketing "price." It is also obvious that the availability of

13. See Saxton Coal Mining Co. v. Coal Comm., 96 F. (2d) 517 (Anp. D. C. 1938); Utah Fuel Co. v. Coal Comm., 101 F. (2d) 426 (App. D. C. 1938), aff', 306 U. S. 56 (1939); Powhatan Mining Co. v. Ickes, 118 F. (2d) 105 (C. C. A. 6th, 1941). But all producers remain subject to the report requirements of $\$ 10$, whether Cutle members ur not. See Powhatan Mfining Co. v. Ickes, id. at 108 . However, the reports required if Code members are much more comprehensive than those required of all pruducers. Sce 5 FED. REG. 1281, 2243, 2412, 3813 (1940); 6 FED. REG. 2451 (1941).

14. 53 Stat. 7, 18 (1939), 26 U. S. C. $\$ \$ 13$ (b), 26(b) (Supp. 1939). See Hcarings on $S .1 .75$ th Cong., 1st Sess. (1937) 26.

15. Applications for exemption on the grounds that particular transactions in coal did not affect interstate commerce, or that the coal was captive within the exemptiun provision, numbered 352 by February 20, 1940. Of these, 142 were withdrawn, 89 dismissed on stipulation, 36 granted, and 4 denied. 81 were still pending. ArTinsser Gis:erai's Report on Administrative Procedure, Monograph 23 (1940) Pt. II, p. y4.

16. "In times of high industrial activity the mines which are owned ur controlled by the consumer, either directly, or indirectly through stock ownership, operate more steadily than mines selling coal on the commercial market." TNI:C REs., sufro note 5, at 266. See Nat. Resources Comm., Exergy Resources axd Nithomal Pelicz (1939) 69.

17. See Clark, The Economics of Over-Heid Costs (1923) 347-352; TNEC ReP., supra note 5, at 237-42, 317; Rostow, Bituminous Coal and the Public Interest (1941) 50 YALE L. J. 543, 553. 
captive mines is a limitation upon the possibility of enforcing minimum prices which much exceed the costs of extracting captive coal. Thus, in that respect, all captive operations affect the administration of the minimum price schedule. But the Act does not protect its minimum price plan by prohibiting consumers of coal to own or to operate mines. On the contrary, it expressly approves of some captive operations by exempting them. No attempt is made to limit the number of exemptions. ${ }^{18}$ Testimony of the drafters of the statute and omission of any provision to the contrary indicate that satisfaction of the conditions for exemption is a permissible means of avoiding price control. ${ }^{19}$ On the other hand, unless the exemption provision is applicable, the Act purports to regulate any "sale or other disposal," which includes "consumption or use . . . by a producer, and any transfer of title by the producer other than by sale." ${ }^{20}$ Furthermore, the price provisions of the Act may not be evaded "by or through the use of subsidiaries, affiliated sales . . . companies or other intermediaries or instrumentalities." 21 Problems of classification thus assume greater significance. Where the producer entirely owns or controls the captive mine, so that prices paid by constumer to operator are bookkeeping entries, significant only to the tax gatherer, a grant of exemption would not substantially contravene the price policy of the Act. But many so-called captive arrangements for which exemption is sought have a more direct relationship to price. Where the producer corporation consists of interests different from those of the consumer, exemption might offer for all practical purposes a means of evading established minimum prices. The task for the courts, therefore, is to interpret the exemption in a way which fulfills both parts of the equivocal policy of the statute: that is, the exemption of some captive operations, and the stubjection of others, which have much the same economic effect, to the Act's minimum price plan.

An arrangement under which coal is produced by employees of the consumer from mines owned by him in fee clearly falls within the exemption provision. There the consumer is a producer engaged in the business of mining coal. For convenience, this arrangement. may be termed the "pure

18. This applies, apparently, not only to captive arrangements existing at the time of the passage of the Act, but also to captive arrangements within the exemption negotiated subsequently. Rejection of an amendment to the exemption stbsection which would have "frozen" the right to secure exempt captive arrangements as of the date of passage of the Act supplies some further evidence to support this conclusion. See H. R. No. 578, 75th Cong., 1 st Sess. (1937) 1, 8; 81 CoNG. REc. 3136 (1937).

19. See Hearings on S. 1, 75th Cong., 1st Sess. (1937) 25-26. Cf. testimony of Judge Warrum: "Take for instance and exclude captive coal from the operation of the allocation feature of this bill and from the Code provisions, and I think that would be followed by a movement everywhere to lease mines for the purpose of operating them as captive mines." Hearings on S. 1417, 74th Cong., 1st Sess. (1935) 36. See also testimony of C. H. Hosford, Jr., id. at 123.

20. $\$ 3(a)$ and (b).

21. $\$ 4-I I-(g)$. 
captive" situation. Difficult problems of classification, however, arise with respect to captive arrangements which deviate from the pure captive pattern. Thus, the consumer's control of the mine may not be based on ownership in fee. It may be based on a part ownership of the fee, a long or shortterm lease of the mine, or a partial or complete stock control of a separate mining corporation. Further, the actual work of extraction of the coal may not be done by the employees of the consumer. It may be performed ly his agent, or by an independent contractor employed by him, or perhaps ly a subsidiary corporation nominally owning the plysical properties.

In the recent case of Powrll v. Gray."2 for example, the Fourth (ircuit Court of Appeals was faced with the problem of classifying an arrangement whereby a railroad company holding a year-to-year lease of mines employed an independent contractor to extract coal for the use of the company. Prior to the establishment of the lease and contract arrangement, the independent contractor had been actively interested and engaged in the commercial uperation of at least one of the mines leased by the railroad. ${ }^{23}$ The leases of the mines and the agreement with the independent contractor matured at the same time, both being renewable from year to year. It also appeared that the leases and the contract were subject to termination at any time the railroad could obtain coal on the open market at a price less than the amount paid to the contractor plus royalties to the lessor, unless the contractor appropriately reduced his fee. ${ }^{24}$ Finding no "sale or other disposal" upon which the price provisions of the Act might operate, the court held the arrangement necessarily exempt. The criterion adopted to determine the question of exemption or non-exemption was a comparison of the characteristics of the transactions involved with those of the conventional sale and its attendant title transfer.

22. 114 F. (2d) 752 (C. C. A. 4th, 1940), aff'd mom., Gray v. Powell, 61 S. Ct. 824 (U. S. 1941), reli'g granted, 61 S. Ct. 938 (U. S. 1941) (assigned for hearing Oetatsr 13, 1941).

23. The independent contractor was an ex-president of an operating company which had worked one of the mines taken over by the railroad pursuant to the agreement in question. The contractor's wife was the majority stochholder in the operating company. It appeared also that a second mine leased by the railroad and managed by the contractor had been controlled by a company of which the contractor's brothers were managers. As a term of the agreement, the contractor was bound, in the case of a breach of the condition subsequent and termination of the agreement by the railroad, to assume the leases of the three mines. Record on Appeal, pp. 126-41, 536-44, Gray v. Powell, 61 S. Ct. 824 (U. S. 1911).

24. Record on Appeal, pp. 35-39, 126-31, 538-45, Gray v. Powell, 61 S. Ct. 824 (U. S. 1941). At the time of the appeal, the rate of compensation allegedly paid the contractor varied from $\$ 1.63$ to $\$ 1.705$ per ton, according to the mine. This was paid at a flat rate per ton with provision for adjustment with changing costs, and an option in the railroad to pay at "cost plus $10 \%$." The original rate on the contracts made in 1934 -approved as a permissible avoidance of the price terms of the NIRA-was about $\$ 1.15$ per ton. Cf. TNEC Rep., supra note 5, at 297, 299: Before coordination the minimum price found for locomotive fuel in price area one was $\$ 2.15$ per ton. 
The legal concept of sale, with its concomitant search for the passage of title, however, seems a useless test for solving the classification problem. A division among captive arrangements will serve the policy of the Act as fully as possible by minimizing in some degree the number of transactions in which less than minimum prices are charged. The Act consists of an attempt to set and to police the enforcement of minimum prices for commerce in coal. ${ }^{25}$ Agreed, therefore, that it applies only to commercial transactions i.c., "sales" - of coal. But the test of "sale" for this purpose should not be assimilated to the literature of the Uniform Sales Act. There is a salc for purposes of the Coal Act, it may be suggested, if the purchaser's interests in the nominal sales price are distinct from those of the seller. Identity of interest should suffice to support the exemption, whether or not title to the coal has passed for other purposes.

Until the decision in the Powell case, the scope of the exemption provision in the operation of the Act had been generally limited. The Bituminous Coal Division ${ }^{26}$ appears to have taken the position that captive coal immunity is to be restricted to those consumer-producers who are engaged in the mining of coal through their own employees. Thus the emphasis is laid on the direct operation element in the "pure captive" situation. In the Powell case, the Coal Division declared that the independent contractor was not a railroad employee or agent, but a separate, independent entity and that, therefore, the railroad was not the "producer" of the coal in question, as that term is used in Section 17(c) of the Act. ${ }^{27}$ This doctrine, carried over from cases involving tort and contract liability, fails to achieve the policy of the Act in the present situation. A more appropriate ground for the decision of the Coal Division probably may be found in its statement that the railroad had not "become a "producer" but had "rather left their

25. See Sunshine Anthracite Coal Co. v. Adkins, 310 U. S. 381, 392 (1940); Northwest Improvement Co. v. Ickes, 111 F. (2d) 221, 224 (C. C. A. Sth, 1940).

26. Bound about by rules requiring reasonable public notice, full hearing, and findings of fact, the Coal Division is given "the power to make and promulgate all reasonable rules and regulations for carrying out the provisions" of the Act, and the findings of fact are made conclusive if supported by substantial evidence. $\$ 2(a)$. While judicial review of Coal Division rules and determinations is provided under $\S 6(\mathrm{~b})$, it may be that a review of a holding involving the exemption provision must be limited to questions of constitutional power, statutory authority, and the basic prerequisites of proof. See Sunshine Anthracite Coal Co. v. Adkins, 310 U. S. 381, 400 (1940); Shields v. Utah Idaho R. R., 305 U. S. 177, 180 (1938); United States v. Idaho, 298 U. S. 105, 109 (1935); but see Consolidated Indiana Coal Co. v. Coal Comm., 103 F. (2d) 124, 128 (C. C. A. 7th, 1939) ; Mallory Coal Co. v. Coal Comm., 99 F. (2d) 399, 405 (App. D. C. 1938).

27. Doctrinally, a corporation could be such a "producer" only through its agents, but an independent contractor is regarded for some purposes as an agent of the cmployer; in such case an identity might be found between the employer and the contractor under the doctrine qui facit per alim facit per se. See Restatement, Agency (1933) $\S \S 1$ (d), 2(3), 2(b), 20, 220; cf. White Mt. Paper Co. v. Morse, 127 Fed. 643 (C. C. A. 1st, 1904). 
'consuner' position . . . unchanged." 28 Of course, every captive producer, coming within or without the exemption provision, is primarily a consumer. But the statement of the Director reveals a policy of preventing consumers from assuming a temporary captive producer status as a part of a plan to obtain, for the immediate present, a supply of coal at less than minimum prices. This antipathetic attitude toward the short-term arrangement stems from the desire to prevent evasion of the price provisions of the Act, and protect the enhanced price structure of the commercial coal market. Thus entrance into a short-term captive agreement, whatever its form, unlike the purchase and direct operation of a mine in the pure captive situation, is regarded as an attempted evasion within the prohibition of Section 4-II-(g). Beyond this, the captive producer under a short-term arrangement is seen to have an unfavorable influence upon the commercial cual market. Under a short-term arrangement, and particularly under an arrangement subject to termination at the option of the consumer, there is, the Coal Division seems to say, a periodical possibility of either a return to purchasing coal in the open market, or a re-exertion of pressure on independent coal operators to enter into captive arrangements. ${ }^{29}$

While the courts which have considered the operation of the captive coal provision have differed radically in their attitudes toward the granting of exemptions, they have ostensibly utilized variations of the same test in solving the classification problem. Favoring the grant of exemptions, the court in Consolidated Indiana Coal Company . Coal Commission $^{30}$ disregarded a corporate entity in order to find a parent corporation which was consuming all the coal produced by its subsidiary a "producer" within the immunity granting section. Since it noted that the corporate entities were not maintained and that sales by the subsidiary to the parent were bookkeeping transactions, the court apparently used a "sale" test on the order of that employed in Porull $v$. Gray. Here, however, the court went beyond the test used in the Porevll case by eliminating from the operation of the price provisions of the Act transactions which were sales only in form. In Keystone Mining Company $v$. Gray, ${ }^{31}$ on a similar set of facts, another court failed to find any ground for ignoring the separate corporate entities. Finding a sale in form, and basing its decision on the legislative history of the captive coal provision, it refused to exempt the particular parent-subsidiary captive arrangement. ${ }^{22}$

28. Cited, Poweil v. Gray, 114 F. (2d) 752, 754 (C. C. A. 4th, 1940), off'd mcm, Gray v. Powell, 61 S. Ct. 824 (U. S. 1941), reli'g granted, 61 S. Ct. 938 (U. S. 1941 ).

29. See Brief for Petitioners, pp. 34-36, Gray v. Powell, 61 S. Ct. 824 (U. S. 1941).

30. 103 F. (2d) 124 (C. C. A. 7th, 1939).

31. 120 F. (2d) 1 (C. C. A. 3d, 1941). Cf. Northwest Improvement Co. v. Iclies, 111 F. (2d) 221 (C. C. A. Sth, 1940).

32. An amendment specifically designed to broaden the exemptiun provision such that the parent-subsidiary captive situation might be immunized was offered and rejected during the final stages of the enacting process. See H. R. REP. No. 578, 75th Cong., 1st 
Despite the decision in the Keystone case, there would appear to be no sound objection to exempting a transaction involving "book-entry sales" of the entire production of a wholly-owned subsidiary to its parent. ${ }^{33}$ In such casc there is an identity of interest between the supplier and the consumer units. In the light of the general purposes of the Act to regulate commerce, the transactions are "non-commercial," and hence, it would seem, outside the purview of the Code provisions. Comparing the parent-subsidiary situation to the admittedly exempt pure captive arrangement, there appears no adequate ground for differentiation in treatment. The arrangements are motivated by the same general considerations; captive production is conducted in the same manner; and the effects of exemption upon the market seem to be identical in both cases. If any exemptions are allowed, it is difficult to see how they can be denied in cases where the consumer is purchasing the output of a wholly owned subsidiary.

Because of the varying interpretations of the purpose and operation of the exemption provision, the necessity of establishing uniform criteria for classification becomes more immediate. Primarily, classification in each particular case might be held to depend upon the effect of exemption or nonexemption upon the minimum price policy of the Act. But the economic consequences of the various arrangements are substantially the same. All equally constitute a way of obtaining coal more cheaply and conveniently than through open market purchase, particularly when market prices are high relatively to operating costs. The problem posed by the Act, however, demands limitation of the number of exemptions. In the interests of simplicity and ease of administration, the most faithful enforcement will probably be provided by a rule which makes exemption as difficult and expensive to obtain as possible. On the other hand, the captive coal exemption provision expresses a secondary policy of the Act. Hence rules for classification must be devised to reconcile the opposing considerations.

The operation of the Act, it has been found, is permissibly affected by the pure captive situation. The predominant characteristic of the pure captive situation is the identity of interest of the supplier and the consumer. Having as a joint, primary aim the most efficient production of coal for a supplying of the consumer's needs, these two economic entities unite to "straddle the market" for coal. Thus it appears that exemption of captive arrangenents wherein the supplier and the consumer of coal have an identity of interest similar to that of the parties to a pure captive agreement will have only a permissible effect on the operation of the Coal Act, and exemption will properly be allowed. Conversely, captive agreements in which identity of

Sess. (1937) 1, 8; 81 Cong. Rec. 3136 (1937). The court held that the rejection of an amendment forbids the reading of the Act as if it had the amended meaning. Keystone Mining Co. v. Gray, 120 F. (2d) 1, 10 (C. C. A. 3d, 1941), and cases cited.

33. See Excerpt from an Analysis by Chairman E. M. Douthat, 81 Cong. Rec. 3013 (1937). 
interest is not found to be a significant element should not be held within the provision.

Under this suggested standard, an arrangement whereby a consumer partly owned a mine in fee, operated it through agents, and consumed its entire output would probably be exempt. The degree of identity of interest between the agent-supplier and the consumer-part owner would present no substantial deviation from that in the pure captive situation, depending upon the consumer's ownership share and the general circumstances surrounding the arrangement. Thus an $80 \%$ ownership share in the fee would strongly indicate an identity of interest between consumer and agent; but a 20\% share in the fee might not in itself be sufficient. Supplemented, however, by a record of a number of years' operation of the property as a captive mine, or by a contract with the other owners to take the entire production of the mine for a given period, or by a contract of some length with the agent to operate the mine, the less substantial ownership might be adequate. In the parent-subsidiary captive arrangement, there would be under this test sufficient identity of interest to found exemption where the subsidiary was wholly owned; or $80 \%$ or $60 \%$ owned, in all probability. But fractional ownership should require additional substantiating evidence.

The captive agreements raising the greatest problem of classification, at the present time are those involving leases of varying terms, and operations through varying legal instrumentalities. Among these types of captive arrangements, the short term lease-contract agreement of the Porioll case probably presents the weakest argument for exemption. Two principal consequences follow from permitting exemption in short-term lease-cuntract situations. Primarily, for reasons previously noted, consumers and indlependent operators alike will seek the benefits of this temporary captive arrangement. ${ }^{34}$ New extra-district competitive opportunities will thereby be opened to all operators desirous of obtaining the stability of a captive operator status, $^{35}$ or seeking a captive agreement because of some competitive disadvantage in selling their coal at minimum prices on the open market..$^{33}$ Under the Coal Act, the enforcement of minimum prices tends to have an allocative

34. Since the Powell decision in the Circuit Court, the Coal Divisiun has received a number of applications for exemption (24 by March, 1941) on the same gruund as there involved. One of these applications related to a contract for only 6200 tons of coal. See Application of Morgantown Glassware Guild, No. 1463FD, filed October 16, 1940; Brief for Petitioners, p. 30, Gray v. Powell, 61 S. Ct. $\$ 24$ (U. S. 1941). The Porvell case rule in operation appears to have an equitable operation as between the great and the small consumer enterprise.

35. See note 16 supra.

36. A typical example is found in the case which involved the Bituminous Coal Producers' Board for District 9, Madisonville, Kentuchy. Here there was sought a change in minimum prices at the mine such that West Kentucky Coal could compete in Market Area 34, Evansville, Indiana, on a parity with Indiana coals. The petition was denied. See Department of the Interior Release, C. D. 323, P. N. 151177, July 30, 1941. Thus a 
effect upon the distribution of production to different market areas, on a basis of reflecting existing competitive relationships. ${ }^{37}$ In negotiating without reference to established minimum prices, therefore, would-be captive operators can compute the lease-contract "price" rate, or fee, on the basis of actual costs of production, and can thus compete for captive arrangements with consumers not within the particular price district established by the Coal Division. Consequently, there will be some effect on the operation of the price policy of the Coal Division, for the negotiation of extra-district agreements will in some measure disturb production allocation. As a variation of the same proposition, it is alleged that exemption of short-term arrangements, with the resulting demand by consumers and competition among operators, would culminate in a race among the operators to obtain captive engagements and thus save a part of the disappearing general market. In the pure captive situation, competition on the captive agreement level and disturbance of the operation of Coal Division price policy would occur, in each case, only once within a certain, and probably extended, period of time. In the short-term lease-contract situation, it is claimed, these influences wotld be felt periodically, at the termination of each agreement. ${ }^{38}$

But the importance of this effect may reasonably be discounted in view of certain countervailing factors. In the first place, extra-district competition on the captive arrangement level will be limited geographically by the importance of freight rates as a cost factor in "price" to the consumer. ${ }^{30}$ Since established minimum prices are somewhat attuned to the total of the different production and sales costs, ${ }^{40}$ even the margin permitted by the captive ar-

producer located at the extremes of a marketing area, and under a freight-cost disadvantage, or one whose production is of the lowest quality in one classification range, will also compete with difficulty. See Powhatan Mining Co. v. Ickes, 118 F. (2d) 105, 107 (C. C. A. 6th, 1941).

37. The "existing fair competitive opportunities" standard [Section 4-II-(b)] for minimum price determination, it has been found, "expresses a pervasive policy of the Act." TNEC REP., supra note 5, at 379.

38. See Brief for Petitioners, pp. 34-36, Gray v. Powell, 61 S. Ct. 824 (U. S. 1941).

39. Freight rates often account for a larger part of the delivered price of coal than the producer's return. TNEC Rep., supra note 5, at 372-73; see Parker, Tue Coni. INDUSTRY (1940) 39-44. Markets are localized because of the low unit value of coal when compared to the high unit cost of its freight. NAT. Resources Coms., op. cit. suprat note 16 , at 79 .

40. Pursuant to the order of the Secretary of the Interior, May 3, 1941, hearings are being currently held to establish new minimum prices (Docket 21, Bituminous Coal Division). However, since it had already been determined at the time of the order that there was "an average national reduction of 18 cents per ton" in production costs over the period August, 1940 to May, 1941, it is apparent that the incentive to makc captive arrangements remains strong within the different marketing areas. See Department of the Interior Release, C. D. 205, P. N. 139700, May 3, 1941. In view of the present upward trend, it is possible that the decrease of unit overhead costs consequent upon the predicted $194110 \%$ increase in production will invalidate the new price schedules before they are put into effect. See Department of the Interior Releasc, C. D. 278, P. N. 
rangement rapidly disappears and captive operation becomes unprofitable with increases in the distance from mine to consumer. Of course, this limitation is less operative in the railroad supplying field, where the consumer's freight charges are part of its own operating costs. ${ }^{11}$ But, in the light of this limitation, the anticipation of a rush by operators to enter unprofitable captive agreements presumes the willingness of numbers of operators in each different marketing area to make contracts, binding for substantial periods, which do not cover cost components of price. While individual sales at a loss were common prior to the establishment of the minimum prices under the Code, ${ }^{42}$ it is doubtful that contracts involving the entire production of a mine, even for the short period of one year, would be negutiated on the same basis. Thus the much-debated allocative feature of the Coal Division's price policy ${ }^{43}$ will be but negligibly impaired, if at all, by permitting short-term lease-contract exemptions.

The second and more important effect of permitting short-term leasecontract exemptions is that transactions involving a very large volume of coal would thereby be removed from the operation of the Code sections of the Act. This would curtail the influence and effectiveness of the Coal Division in its function of price determination and establishment of marketing rules and regulations, for the coal base to which such prices and regulations would be applicable would be greatly reduced.44 Similarly, the burden of the expense of administering the Code would fall more heavily upon the remaining Code members. Finally, exemptions widely granted on the basis of one-year captive agreements permit a recurring possibility of the return of large captive producers to the open market as purchasers or as prospective captive employers. Such a threat hanging over the market would have an influence

147920 , June 29, 1941. This raises one of the basic criticisms of the Act and its price machinery: the "lag" of price determination and establishment behind shifting cost considerations. TNEC REP., supra note 5, at 316-18.

41. The railroad transports coal used in carrying on its business at cust to itself, without violating the provisions of the Hepburn Act, 34 ST.r. $5 \$ 5$ (1906), 49 U. S. C. $\S 1(8)$ (1934); 29 Ops. ATTY. GEN. 587 (1912).

42. See Sunshine Anthracite Coal Co. v. Adkins, 310 U. S. 381, 395 (1940); Carter v. Carter Coal Co., 298 U. S. 238, 330 (1936) ; Appalachian Coals, Ine. v. United States, 288 U. S. 344, 361-64 (1933) ; TNEC REP., stipra note 5, at 254.

43. See Rostow, Bituminous Coal and the Public Interest (1941) 50 YaLe L. J. 543, 613; Hamilton, Coal and the Econonn-A Demurrer (1941) 50 YALE L. J. 595.

44. In 1940 there were produced in districts 1 to $15,28,898,807$ tons of "exempt" coal, and 55,254,061 tons were disposed of by "controlled" sales, or sales "other than by an arms' length transaction." The total, $84,152,868$ tons, comprises the trade version of captive production; should all this coal be exempted under the captive cual provision, even without further conversion of independent operators to an exempt captiveoperator status, approximately $20 \%$ of the total production in districts 1 to 15 would escape Code regulation. Revised Detall of Pronucraxg, Adamistrative, ard Seunizg Costs For the Calendar Year 1940, op. cit. stpra note 2; see Nat. Bureau of Eco:. Research, Report on Prices in the Bituainous Code Intustry (1938) 8-9 (20 tu $25 \%$ of total tonnage). 
subversive of the avowed aim of the statute to effect "stabilization of the industry." 45 This disturbing effect is not found in the pure captive situation, where a shift back to the market is more difficult because of the stabilizing influence of the substantial investment by the consumer in coal mining facilities. ${ }^{46}$ Hence a grant of exemption in the short-term lease-contract situation of the Powell case will have an effect upon the operation of the Act substantially more adverse than that arising from pure captive exemptions. Briefly described, the evils to be anticipated from exemptions of shortterm lease-contract arrangements are created principally by the impermanence of the relationship. In other words, absence of a well-established identity of interest between the consumer and the supplier reveals the true nature of the agreement as an alternative form of sales contract, contingent merely upon market price and thus lacking the essential characteristics of the captive arrangements contemplated for exemption.

Tested further by the identity of interest rule, however, it is apparent that lease-contract arrangements in general need not categorically be denied exemption. An agreement designed for a longer term might well satisfy the test. In such case the lessee-consumer might have a substantial interest in common with the supplier, and he with the consumer, even though the supplier were formerly an independent operator of the mine. ${ }^{47}$ As the term of the agreement is increased, the community of interest becomes more stable, and therefore more significant. Whether lease-contracts should be designed to have operation for two, or ten, or twenty years, or longer in order to raise a sufficient identity of interest is a controversial question embracing matters of economic and political policy. Its determination under the suggested identity of interest rule would be made, after a full hearing before a board acquainted with the field, ${ }^{48}$ upon a consideration of all the circumstances.

In operation, the identity of interest criterion for determination of the classification question would be applied to the facts of each captive situation as of the time of the petition for exemption. ${ }^{40}$ The easily established facts of the legal relations which form the basis of the agreement would be primarily infuential. Thus the direct relationship of the consumer to the mine on at substantial investment basis or by an important contract commitment will tend to establish an identity of interest between the consumer and the supplier. Similarly, an agreement binding the supplier to the consumer as

45. Sunshine Anthracite Coal Co. v. Adkins, 310 U. S. 381, 388 (1940); sec Appalachian Coals, Inc. v. United States, 288 U. S. 344, 364 (1932); Hamilton, supra note 43, at 609-10, n. 23, 24. Cf. Holden v. Hardy, 169 U. S. 366, 397 (1898).

46. Shutting down of captive mines in order to purchase below cost in the open market is no longer an alternative in view of the enforcement of minimum prices.

47. See notes 23 and 24 supra.

48. See note 26 supra.

49. Procedure for obtaining exemptions is described in Attonney Generul's Committee on Adainistrative Procedure, Monograph 10 (1941) Pt. 10, pp. 39-53. 
an employee, agent, or independent contractor over a lengthy period will have significance. On the other hand, the possibility of termination of the arrangement on the occurrence of certain conditions subsequent, ${ }^{, 0}$ or through the exercise of an option by either party, will be a countervailing factor. But provisions for periodic renewal of agreements and adjustment of the fee to costs may give supplementary indication of requisite identity of interest in certain cases. Other elements may also he found significant with respect to the duality of interest: the history of the negotiations which gave rise to the agreement, the respective bargaining positions from which the parties negotiated, and the coal record of the consumer and the supplier.

Finally, the requirement of a substantial identity of interest as a requisite to exemption under the captive coal provision will virtually assure a linitation of the total numbers of exemptions permitted. This will naturally result as the alternative burdens of large investment or assumption of relatively lung term commitments discourage the so-called captive arrangements which are manifestly contingent on market price. Strict application of the rule should be subject, however, to a consideration of the possible discriminatory effect to be anticipated from rigid limitations on grants of exemption. Thus, finding an identity of interest only in the circumstances of a pure captive situation would effectually withhold the advantages of captive exemption from the less affluent consumer, who could not afford the investment ur the risk of direct ownership and operation of a mine. Such an inequitable operation of the exemption provision is to be avoided where this is pussihle consistently with the more elemental considerations heretofore set out. ${ }^{\text {II }}$ Generally, a policy limiting exemptions seems consonant with the operation of the provision apparently intended by Congress. The practical validity of direct marketing, ${ }^{52}$ acknowledged by the Act in the exemption provisiun, is recognized under the identity of interest rule (and the limitation upun exemption which is the necessary concomitant thereof) yet the principal ends of the Act will obtain.

The ultimate solution of the problem of classification must lis fuund, therefore, in a consideration of the legal relations and the special circumstances surrounding the production-consumption arrangement in each individual case.

50. See note 23 supra.

51. It might also be argued that the enforcement of minimum prices, as a result of refusing exemption in the lease-contract case, would require allocation of the price between the lessor and contractor, in violation of the right of freedom of contract insured by the Fifth Amendment; or that Congress did not intend a regulation of costs uf production, as this allocation would seem to entail, but only prices in commerce. Sce Atlanta v. Coal Commission, 26 F. Supp. 606, 610 (D. Cul. 1939), aff'd, $30 S$ U. S. 517 (1939); Nebbia v. New York, 291 U. S. $5(12.525$ (1934); West Coast Hotel Co. v. Parish, 300 U. S. 379, 391 (1937). But see (1940) 27 V.. L. Rer. 117.

52. See Burns, The Decline of Competition (1936) $431-45 ; 4$ Dewra, Fina:chal Policy of Corporations (1920) 55-56; Eckes. (uill, Iros, A:o Wrar (1920) $255-61$. 